\title{
Weonomics
}

Central European Review of Economics \& Finance

Vol. 24, No. 2 (2018), pp. 21-43

DOI: $10.24136 /$ ceref.2018.008

Received: 25 January 2018. Accepted: 3 April 2018

Helena ŻUKOWSKA ${ }^{1}$

\section{THE CHARACTER AND EFFECTS OF SANCTIONS IMPOSED ON RUSSIA IN CONSEQUENCE OF AGGRESSION AGAINST UKRAINE}

The purpose of this article is to present sanctions applied to Russia after 2014 by the countries of the European Union, the United States, Canada, Switzerland and other. In addition, an attempt was made to determine the impact of sanctions on Russia's economy based on the analysis of Russia's economic situation. This task was not easy, since the economic situation of Russia in the analysed period was influenced by two significant factors - the sanctions and a fall in the prices of fossil fuels. In the author's opinion, the economic sanctions imposed on Russia have adversely affected the development of the Russian economy after 2014. Russia's GDP has decreased, GDP growth rate has slowed down, global demand has declined, prices and interest rates have risen. Inflation has increased, the rouble has become devalued, the amount of foreign exchange reserves has gone down, and life quality of Russian citizens has deteriorated. The sanctions of the Western states against Russia as well as the sanctions reciprocally applied by Russia against the broadly understood foreign countries have negatively influenced the economies of many Western states which have also been affected by worse conditions of economic growth after 2014. The final conclusion of this text is the conviction that the introduction of economic sanctions against Russia and the isolation of Russia on the international stage has led to the weakening of Russia's economic development in the short term. In the longer term, the impact of sanctions on the Russian economy has been compensated. In this context, a question arises about the effectiveness of political and economic sanctions as a tool for restrictions in international relations. Higher effectiveness of sanctions will be ensured in small economies, but lower in the case of large economies such as Russia.

Keywords: sanctions against Russia, Russia's economy, consequences of sanctions on the Russian economy.

JEL Classification Codes: F51.

\footnotetext{
${ }^{1}$ Associate professor, PhD Habil, The Catholic University of Lublin, Poland.
} 


\section{Introduction}

Russia's involvement in the conflict in Ukraine in 2013 and 2014 and annexation of Crimea and Sevastopol caused many states to protest and take actions condemning and denouncing such a policy of Russia. Various types of sanctions, including economic ones, have been imposed on Russia by many states, such as the EU, USA, Canada and Switzerland.

The main objective of the article is general assessment of the consequences of using economic sanctions in relations between countries. Another aim is to present the effects of sanctions applied against Russia on the Russian economy.

\section{Sanctions of the European Union}

In specific situations the European Union undertakes actions aimed at persuading individuals, economic entities and governments of countries affected by sanctions to change their policies or conduct. In this way, the EU promotes objectives of the Common Foreign and Security Policy.

Among the tools of the EU Common Foreign and Security Policy there are also sanctions. Sanctions are instruments limiting certain actions undesirable by the European Union, as well as preventive measures enabling the EU to react quickly to political events and situations which stand in contradiction to its objectives and values. Sanctions are applied in response to terrorist incidents, spread of nuclear weapons, infringement of human rights, annexation of a foreign territory or purposeful destabilization of a sovereign state. Goals of sanctions are:

- safeguarding of values, vital interests and security of the EU,

- keeping peace in the world,

- strengthening and supporting democracy, human rights and rules of international law,

- preventing conflicts and increasing international security (How and When the EU Adopts Sanctions, 2017).

All the EU sanctions are fully compliant with international agreements and regulations of the international law. Sanctions can be imposed on:

a) governments of non-EU countries, due to their policies;

b) economic entities and other institutions financing these policies;

c) groups and organizations, mostly terrorist groups;

d) individuals supporting particular policies, e.g. involved in terrorist activities.

Sanctions are applied by the EU is such a way so that civilian populations, not responsible for particular policies and actions of governments, should be affected as little as possible (Guidelines on implementation and evaluation of restrictive measures, 2012; Best practices for the effective implementation of restrictive measures, 2016). 
Depending on the scope of influence, sanctions can be divided into those targeted at individuals and at economic entities (How and When the EU Adopts Sanctions, 2017).

Furthermore, depending on the type of influence, we can distinguish diplomatic sanctions (sanctions in a broad sense), sanctions in a narrow sense, as well as sanctions applied on the EU's own initiative or jointly with the United Nations (Types of sanctions, 2017).

Diplomatic sanctions are e.g. suspension of diplomatic relations with a given country, or coordinated recall of diplomatic representatives of the EU and its member states from a country affected by sanctions.

Sanctions in a narrow sense must have a specific legal basis in the EU treaties. They include: embargo on purchase and sale of weapons; entry restrictions - a ban on travelling for people put on a special list: these people cannot enter the EU and if they are EU citizens they cannot enter other member states; freezing of assets of individuals or entities put on a special list; economic sanctions that is restrictions on specific business sectors, e.g. a ban on import or export of certain goods, a ban on investment, a ban on provision of some services.

Sanctions on the EU's own initiative or on the initiative of the United Nations are distinguished according to the initiating entity. Sanctions can be imposed on the EU's own initiative or in order to implement a resolution of the UN Security Council.

a) UN sanctions are implemented by the EU when they are adopted by the UN Security Council.

b) Mixed sanctions pertain to situations when the EU acts jointly with the UN and then the EU can toughen the UN sanctions or use additional measures apart from those imposed by the UN Security Council.

c) Autonomous sanctions are those introduced by the Council of the European Union on its own initiative.

Sanctions are adopted by the Council of Europe at the motion of the High Representative of the Union for Foreign Affairs and Security Policy. The decision about sanctions must be taken unanimously by all members of the Council of Europe. If a decision about introduction of sanctions provides for asset freezing or other economic and financial sanctions of the EU, the Council's resolution is necessary to implement them. The Council notifies the European Parliament that such a resolution has been adopted. The resolution contains a detailed list of measures and information how to implement them. Furthermore, as a legal act extending all over the EU, it is binding on each individual and each entity in the EU (enterprises, public bodies etc). Both decisions and resolutions of the Council become effective upon their publication in the Official Journal of the European Union. A decision and a resolution are enacted together so that their effects could occur at the same time. Individuals and entities on whom asset freezing or a travel ban have been imposed are informed about the sanctions either directly or 
through an announcement published in the Official Journal of the European Union, the C series (How and When the EU Adopts Sanctions, 2017).

All sanctions are reviewed at least once a year. Moreover, individuals on whom sanctions have been imposed can file a substantiated motion to the European Council for reconsideration of the decision about sanctions.

\section{The EU sanctions in response to the crisis in Ukraine}

In connection with hostile actions towards Ukraine taken by Russia in 2013 and 2014, that is deliberate destabilization of Ukraine and illegal annexation of Crimea, the EU has introduced a broad range of sanctions against Russia since March 2014, such as:

a) diplomatic measures,

b) individual sanctions in the form of asset freezing and travel restrictions on natural and legal persons,

c) restrictions on economic relations with Crimea and Sevastopol,

d) economic sanctions and restrictions on economic cooperation (EU restrictive measures in response to the crisis in Ukraine, 2017).

\section{Diplomatic measures}

The summit EU-Russia was cancelled in 2014. The member states decided not to hold meetings with Russia at regular bilateral summits. Moreover, bilateral talks with Russia on visa issues were also suspended. On 4-5 June 2014, instead of G8 summit in Sochi, G7 summit was organized in Brussels. Since then, meetings of G7 states have been held. Furthermore, the EU states have backed up suspension of negotiations on Russia's accession to the Organisation for Economic Co-operation and Development $(\mathrm{OECD})$ and to the International Energy Agency.

\section{Individual sanctions targeted at Russian and Ukrainian natural and legal persons}

Individual sanctions include mostly freezing of assets and restrictions on travel of natural persons and representatives of legal persons. In 2014-2017 such sanctions were imposed on 150 natural persons and 40 legal persons whose actions infringed territorial integrity, sovereignty and autonomy of Ukraine. For instance, on 21 November 2017 sanctions for infringement of territorial integrity of Ukraine were imposed on the Governor of Sevastopol (EU restrictive measures in response to the crisis in Ukraine, 2017).

Individual sanctions, effective since March 2014, have been maintained and regularly extended, and in September 2017 they were prolonged until 15 March 2018. 


\section{Sanctions for misappropriation of Ukrainian public funds targeted at citizens of Ukraine}

In March 2014 the European Council decided to freeze assets of people responsible for misappropriation of Ukrainian public funds. These sanctions have been extended until 15 March 2018.

\section{Restrictions on economic relations with Crimea and Sevastopol}

The Council of Europe adopted restrictions in response to the illegal annexation of the territory of Crimea and Sevastopol by Russia. These restrictions are binding on the EU citizens and the EU-based companies. They are limited to the territory of Crimea and Sevastopol and comprise:

a) a ban on import of goods from Crimea and Sevastopol to the EU,

b) restrictions on trade and investment in certain sectors of economy and infrastructure projects,

c) a ban on providing tourist services by the EU enterprises in Crimea and Sevastopol,

d) a ban on export of certain goods and technologies (EU restrictive measures in response to the crisis in Ukraine, 2017).

On 19 June 2017 the European Council extended these sanctions until 23 June 2018.

\section{Economic sanctions against Russia in certain sectors of economy}

In July and September 2014 the EU imposed economic sanctions on trade with Russia in selected sectors of economy. In March 2015 the EU leaders decided that lifting of the sanctions would be conditional upon full implementation of the Minsk agreements aimed at solution of the conflict in Ukraine. As it has not happened, the economic sanctions have been extended and they are currently binding until 31 January 2018. These sanctions comprise:

- limitation of access of certain Russian banks and companies to the EU financial market,

- a ban on export and import of weapons,

- a ban on export of dual-use products to Russia (that is products which can be used for military purposes),

- limitation of Russia's access to technologies and services which can be used for production and extraction of crude oil from the seabed or in Arctic.

\section{Restrictions on economic cooperation with Russia}

In July 2014 the EU introduced restrictions on economic cooperation with Russia:

- an appeal was lodged with the European Investment Bank to suspend approval of new financing operations in the Russian Federation, 
- the EU member states agreed to coordinate their positions within the Board of Directors of the European Bank for Reconstruction and Development in order to suspend also the financing of new operations with participation of Russian entities,

- the implementation of the EU programmes of bilateral and regional cooperation with Russia was reassessed and some of them were suspended.

To sum up, the EU sanctions have been imposed on such natural and legal persons whose actions pose a threat to sovereignty and territorial autonomy of Ukraine, mostly from Russia, but also from Crimea and from the regions of Donetsk and Luhansk (Ukraine). The list of individuals covered by the EU sanctions has been modified and e.g. in December 2017 it contained 160 people, whereas the number of institutions and organizations was 40 (List of persons and entities under EU restrictive measures over the territorial integrity of Ukraine, 2017).

\section{Sanctions of other highly developed countries against Russia}

\section{The United States}

The United States introduced individual sanctions in the relations with Russia already on 17 March 2014. First, a list of 11 people covered by sanctions was published. These were mostly people from the administration of the President of Russia (adviser to the President) and the Russian government (the Chairman of the Federation Council and the Prime Minister and Deputy Prime Minister of Crimea). On 20 March 2014 the list was extended to include 20 more people from the central authorities (the government and the parliament of the Russian Federation). In March the cooperation with Russia on combating drugs was also suspended (Kublik, 2016).

In April 2014 economic sanctions were introduced - American-Russian military and energy projects (including nuclear energy) were suspended, and a ban on export of military products to Russia was imposed. Moreover, sanctions were extended to include further individuals representing important Russian companies from the oil and gas sectors (altogether 7 people from oil companies located in Crimea and about a dozen of people and 17 Russian enterprises from the banking and fuel sectors).

In June 2014 individual sanctions were imposed on further 6 people from the authorities of two Ukrainian regions: Donetsk and Luhansk supporting Russia's aggression against Ukraine.

In July 2014 sanctions targeted at Russian banks and fuel companies were introduced. Assets of these entities were frozen in American banks. Furthermore, Russian companies could not be granted credit by American banks for a period longer than 90 days. Moreover, licensing of export to Russia was introduced pertaining to such goods as: equipment for oil extraction from the seabed and in Arctic, and products for the construction industry. 
In August and September 2014 sanctions were imposed on several more Russian banks, including the largest Russian bank - Sberbank of Russia - and the period of granting credit to all Russian banks was shortened from 90 to 30 days. Furthermore, 5 companies from the defence industry were denied access to the US-based assets. A total ban on export of goods, services and technologies for the Russian mining industry was introduced, as well as a ban on granting credit to many enterprises from the Russian energy industry.

Moreover, in December 2014, a ban on export of American goods to Crimea and a ban on import from Crimea were introduced. In addition, sanctions were imposed on 17 natural persons and 7 legal persons operating in Crimea and on the leaders of the Ukrainian separatists.

In March 2015 the above-mentioned sanctions were extended for the whole year 2015 , and the list of entities covered by sanctions was further expanded to include the Euroasian Youth Union and a branch of one of the Russian banks, operating in Crimea. Moreover, sanctions were imposed on 14 people - citizens of Russia, Crimea and the Ukrainian separatist republics of Donetsk and Luhansk.

In the subsequent months of 2015 the scope of sanctions was broadened:

- in July sanctions were extended to include further 11 natural persons and 15 legal persons, mostly from Russia but also from other countries, e.g. from Finland. Restrictive measures were applied against 35 entities connected with Vneshtorgbank and Rosneft company;

- in August the US government suspended cooperation with Russia (credit granting and export of equipment) on oil extraction in the Sea of Okhotsk,

- in December the US Department of the Treasury imposed sanctions on further 11 individuals and 109 enterprises mostly from the financial, fuel and defence sectors.

As a result of the restrictive measures introduced, at the end of 2015 the US sanctions covered 110 people and 209 enterprises from Russia, Crimea and two separatist republics of Ukraine - Donetsk and Luhansk.

In general, the US sanctions were applied to basically the same entities as the EU sanctions. The US government declared its intention to exert pressure on Russia by means of sanctions until Russia fully carries out the provisions of the Minsk agreements on stopping fights in Donbas and restoring Ukraine's control over its territories. Hence, the EU position on extension of the binding sanctions for the years 2016 and 2017 was adopted (Wsie sankcji zapada protiw Rosii, Retrieved October 8, 2017 from: http://tass. ru/mezdunarodnaja-panorama/1055587/2).

\section{Canada}

Canada introduced first sanctions against natural and legal persons „posing a threat to sovereignty and territorial integrity of Ukraine" simultaneously with the USA, that is on 
17 March 2014. The sanctions were targeted at 7 people holding public offices in Russia and 3 people from Ukraine. These sanctions consisted in asset freezing and a ban on granting entry visas to Canada.

After this date, the list of people covered by the sanctions was extended. On 18 March 2014 sanctions were imposed on 11 Russian and 6 Ukrainian political activists, and on 21 March also on the employees of the central bank (Bank of Russia) and 14 Russian politicians. On 12 April the list of people covered by sanctions was further extended to include the chairmen of election commissions in Sevastopol and Crimea, as well as a company from the fuel sector - Chornomornaftogas. Then, on 21 April, sanctions were imposed on 2 banks and 9 Russian individuals from the world of politics and business.

On 4 May 2014 Canada applied further sanctions against 16 Russian enterprises and banks, and on 12 May against 12 people ( 6 Russian citizens and 6 people from South-Eastern Ukraine). In June 2014, sanctions were imposed first on 11 citizens of Russia and Ukraine and then on more than 20 people and 10 enterprises and banks. In the subsequent months of 2014, 2015 and 2016 the sanctions were maintained and extended to include further people, institutions and companies from Russia, Crimea, Sevastopol and the Ukrainian separatist republics - Donetsk and Luhansk. At the end of 2016 the sanctions imposed by Canada covered 176 natural persons and 102 legal persons (institutions and enterprises) (Wsie sankcji zapada protiw Rosii, Retrieved October 8, 2017 from: http://tass.ru/mezdunarodnaja-panorama/1055587/4).

After 3 November 2017 Canada introduced further sanctions against 30 Russian citizens responsible for the so-called Magnitsky case. Sergei Magnitsky, a Russian lawyer, investigated financial crimes in Russia, e.g. illegal taking over the ownership of foreign investments in Russia. He was arrested in 2009 on a feigned charge of fiscal crimes and died in a Russian prison as a result of being beaten. The group of people covered by sanctions includes both representatives of mafia structures and officials of the Russian judiciary and tax offices (Russia condemned Canada's sanctions against 30 Russian citizens, Retrieved November 5, 2017 from: https://wiadomosci.onet.pl/swiat/ rosja-potepila-sankcje-kanady-na-30-jej-obywateli/fvkp03b).

Since the introduction of the first sanctions against Russia, that is since 17 March 2014, Canada has been extending its list of people and institutions affected by sanctions. In November 2017 the list of individuals covered by sanctions comprised over 200 people, whereas the list of enterprises and organizations contained more than 100 entities (Sankcii Kanady w otnoszenii Rossii. Dosie, Retrieved October 8, 2017 from: http://tass.ru/info/4702366). 


\section{Switzerland}

As a consequence of the negative evaluation of the Russian government's position in the conflict in Ukraine, on 19 March 2014 Switzerland broke off the talks with Russia over negotiations of free-trade agreements (WTO). On 26 March 2014 Switzerland stopped the supply of military products to Russia and ceased to finance trainings of Russian servicemen, and on 2 April introduced restrictions on conducting monetary settlements in Switzerland for 33 Russian enterprises. As a result, from March to August 2014 Switzerland imposed sanctions on 87 people and 20 institutions and enterprises from the aviation industry and the financial sector (Wsie sankcji zapada protiw Rosii, [online:] http://tass.ru/mezdunarodnaja-panorama/1055587/5 [Retrieved October 8, 2017]).

In comparison to the EU, USA and Canada, Switzerland's sanctions against Russia were far less severe and affected a smaller number of citizens.

\section{Sanctions of other countries against Russia after its aggression towards Ukraine}

Although the majority of states worldwide negatively evaluated Russia's position in the conflict in Ukraine, they did not take an unequivocal stance towards application of economic sanctions against citizens and companies of Russia, Crimea and the separatist republics of Donetsk and Luhansk. Economic sanctions against Russia, of various forms and scope, have been imposed by the United States, Canada, Switzerland, Australia and Japan and the majority of the EU states. However, it should be emphasized that the attitudes of the EU states towards introduction of sanctions are not uniform. In July 2014 as many as 9 EU countries (France, Germany, Luxembourg, Austria, Bulgaria, Greece, Cyprus, Slovenia, Italy) were cautious about using sanctions against Russia, despite their consent to the sanctions granted in 2014 (all the EU states voted for introduction of sanctions because this decision has to be unanimous). Nevertheless, representatives of some EU countries spoke against sanctions:

- „sanctions do not solve anything” (Prime Minister of Slovakia),

- "sanctions should be changed because they do not produce expected effects" (President of the Czech Republic),

- "sanctions is a road to nowhere” (Prime Minister of Greece) (Wsie sankcji zapada protiw Rosii, [online:] http://tass.ru/mezdunarodnaja-panorama/1055587/7 [Retrieved October 8, 2017]).

\section{Summary of the list of sanctions used against the aggressors towards Ukraine}

Sanctions for purposeful destabilization of Ukraine and illegal annexation of Crimea - against Russia, Crimea and the Ukrainian separatist republics (Donetsk and Luhansk) 
have been introduced by several countries of the world. The sanctions have been imposed on natural persons, state institutions, community organizations and legal entities, mostly enterprises. Comprehensive and detailed data about the entities covered by the sanctions is available also in information materials of the Russian News Agency TASS, which should be evaluated positively (Wsie sankcji zapada protiw Rosii, Retrieved October 8, 2017 from: http://tass.ru/mezdunarodnaja-panorama/1055587/8).

In the group of natural persons sanctions have been imposed on:

- Russian politicians and state officials: 78 people,

- Russian businessmen: 16 people,

- other Russian citizens (4 people) who actively support the Russian aggression against Ukraine (e.g. leaders of a youth movement or the leader of the "Night Wolves" Motorcycle Club),

- citizens of Crimea: 29 people,

- citizens of other countries: 2 people (Sweden and Finland),

- political activists representing Donetsk Republic and Luhansk Republic: 75 people,

- former President of Ukraine - Viktor Yanukovych, his family members and people from his close environment: 20 people,

- Russian community organizations: 2 (Euroasian Youth Union, „Night Wolves” Motorcycle Club),

- various state institutions and community organizations of the separatist republics of Donetsk and Luhansk (25), including Donetsk and Luhansk Republics themselves, about a dozen of armed military units, unions of enterprises, political and social movements and associations supporting Russia's aggression against Ukraine.

The group of enterprises (legal persons) affected by sanctions of the USA, Canada and the EU has comprised, in various periods, over 350 Russian and foreign entities. Each of the countries imposing sanctions took individual decisions to use them against particular entities. There is not one coordinated register of entities covered by sanctions, even though some individuals and enterprises are listed among the entities on which even several countries have imposed their sanctions.

Sanctions applied against enterprises differ in character. Two types of sanctions can be distinguished:

- asset freezing and a ban on conducting operations of various levels,

- sector sanctions (against the fuel sector, financial sector or defence sector) consisting in restrictions on export, re-export, import and credit granting.

The longest list of legal persons covered by sanctions has been compiled in the USA: it contains 345 enterprises. Among them, 232 are covered only by the sector sanctions and 11 only by restrictions on international trade. 58 legal persons on which the US sanctions have been imposed are registered outside Russia ( 9 in Cyprus, 5 in Switzerland, 3 in the Netherlands and the rest in other countries). 
Taking into account the types of enterprises affected by sanctions, various restrictive measures have been imposed on 122 banks or other financial institutions, 84 enterprises from the new technologies sector and the defence sector, 85 enterprises from the fuel sector and energy sector, 21 transport companies, 16 construction companies and 5 wine producing companies in Crimea (Wsie sankcji zapada protiw Rosii, Retrieved October 8, 2017 from: http://tass.ru/mezdunarodnaja-panorama/1055587/8).

Table 1. Economic sanctions imposed on Russia

\begin{tabular}{|c|c|}
\hline Economic sector & List of sanctions \\
\hline Oil sector & $\begin{array}{l}\text { 1. Restrictions on cooperation with selected enterprises from the oil sector and associ- } \\
\text { ated companies from other economic sectors } \\
\text { 2. A ban on export to Russia of technologies for oil extraction and processing } \\
\text { 3. Freezing of existing cooperation agreements and refusal to sign new cooperation } \\
\text { agreements under new projects }\end{array}$ \\
\hline Gas sector & $\begin{array}{l}\text { 4. Restrictions on cooperation with selected enterprises from the gas sector and asso- } \\
\text { ciated companies from other economic sectors } \\
\text { 5. Freezing of existing cooperation agreements and refusal to sign new cooperation } \\
\text { agreements under new projects }\end{array}$ \\
\hline $\begin{array}{l}\text { Financial sector } \\
\text { and banking sector }\end{array}$ & $\begin{array}{l}\text { 6. Freezing of financial assets of Russian natural and legal persons } \\
\text { 7. Separation of Russia's banking structures from international payment systems } \\
\text { 8. Restrictions on placement of financial means in foreign banks } \\
\text { 9. Restrictions on access to bank loans for Russian entities } \\
\text { 10. Restrictions on conducting business activity abroad for Russian entities }\end{array}$ \\
\hline Defence sector & $\begin{array}{l}\text { 11. A ban on conducting operations with Russia in the area of export and import of } \\
\text { weapons } \\
\text { 12. A ban on export of dual-use products to Russia, as well as any other technologies } \\
\text { which can be used for defence purposes }\end{array}$ \\
\hline Other & $\begin{array}{l}\text { 13. Sanctions against particular people, institutions and organizations of the Russian } \\
\text { Federation } \\
\text { 14. A ban on financing investment projects, supply of materials and equipment for } \\
\text { objects of infrastructure, transport and energy sector of entities from Russia, Crimea } \\
\text { and Sevastopol }\end{array}$ \\
\hline
\end{tabular}

Source: Łoginova I. W., \& Titarienko B. A. (2015). Ekonomiczeskije sankcji protiv Rossii, Aktualnyje Woprosy Ekonomiczeskich Nauk, no. 47, 41-42.

Even though President of Russia Vladimir Putin expressed in the media no concern about any significant impact of economic sanctions on the Russian economy, experts pointed to a number of threats to Russia's economic growth after the introduction of sanctions. Effects of sanctions have been observed both in the Russian economy and in economies of other countries of the world (both imposing sanctions and neutral in this respect). Increasingly, in publications of Russian authors there are expectations that sanctions against Russia should be lifted soon (Barkowskij \& Ałabjan, 2015). 


\section{Effects of economic sanctions}

Effects of economic sanctions imposed on Russia in 2014 should be perceived from the following two perspectives, as:

- effects of foreign sanctions on Russia's economy,

- effects of Russia's embargo on economies of the countries using sanctions.

After three years since of the introduction of sanctions, statistical data demonstrate that they have caused considerable losses for the Russian economy. A slowdown in GDP growth in 2014-2017 is estimated at $8.4 \%$. As a result of a decrease in crude oil prices on the global market, state budget revenue has dropped by ca. 400 bn USD. In total, as a result of economic sanctions imposed on Russia, losses amount to almost 170 bn USD (Nowicki, 2017).

Moreover, sanctions result in worse conditions of economic development for the countries using them. According to data of the Austrian Institute of Economic Research, the sanctions imposed on Russia only until 2016 inclusive cost the EU almost 18 bn EUR and a loss of 400,000 workplaces. The largest economic losses due to the introduction of sanctions against Russia were sustained by the German economy (over 6 bn EUR and 97,000 workplaces). Austria lost ca. 550 million EUR and 7,000 workplaces, and Austrian export to Russia has decreased by almost $40 \%$. Due to the cooling of the economic relations with Russia Poland has lost 1.4 bn EUR and has ranked second in the list of the EU states the most harmed by the introduction of sanctions against Russia (Nowicki, 2017).

\section{The economic situation of Russia in the period covered by the economic sanctions}

The macroeconomic data demonstrate that 2014-2016 was a difficult period in the development of the Russian economy, also as a consequence of the sanctions imposed. However, it is not easy to isolate solely the impact of the Western sanctions on the Russian economy due to the fact that the development of the Russian economy in that period was adversely affected not only by the introduction of economic sanctions on a broad scale but also by a drop in crude oil prices. Even though the drop in oil prices was not directly associated with the sanctions introduced, it was a negative factor in the Russian economy. Both these circumstances produced a synergy effect and strongly contributed to adverse development trends in the Russian economy during that period.

As it is impossible to isolate the influence of particular development factors of the Russian economy, Russia's situation shall be discussed below in the context of two determinants of development - the sanctions and a drop in oil prices.A drop in oil prices

The introduction of economic sanctions against Russia coincided with a significant drop in oil prices on the global market. The price of oil was going down since mid-2014. 
While at the beginning of 2014 Brent crude oil cost almost 120 USD per barrel, in the middle of the year the price was only ca. 50 USD per barrel. At the beginning of 2016 oil cost only ca. 30 USD and in October 2017 the price rose to ca. 60 USD per barrel.

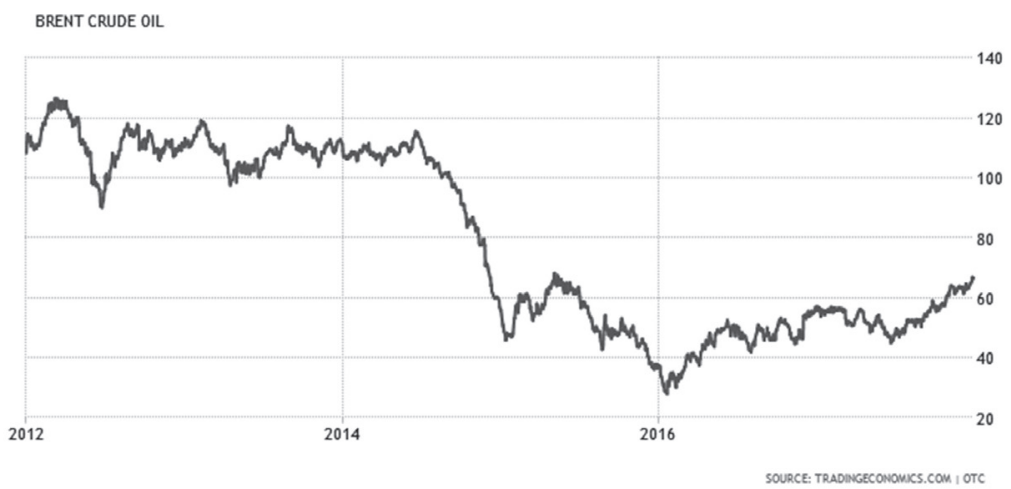

\section{Graph 1. Oil price in 2012-2017 (in USD per barrel)}

Source: Trading Economics. Retrieved December 4, 2017 from: https://pl.tradingeconomics.com/commodity/ brent-crude-oil; Graph: https://d3fy651gv2fhd3.cloudfront.net/charts/historical.png?s=CO1\&v=20171208230000 \&d1=20120101\&d2=20171231

\section{Change in exchange rate}

In the years 2014-2017 there was strong depreciation of the rouble (a drop in value of the rouble). From the beginning of 2014 until the beginning of 2015 the price of the US dollar rose from 34 to 65 roubles, and in certain periods of 2016 even to 75 roubles for 1 USD (Bugatova \& Abelguzin, 2015). In 2017 the price of the US dollar went down slightly and it fluctuates around 60 roubles for the US dollar.

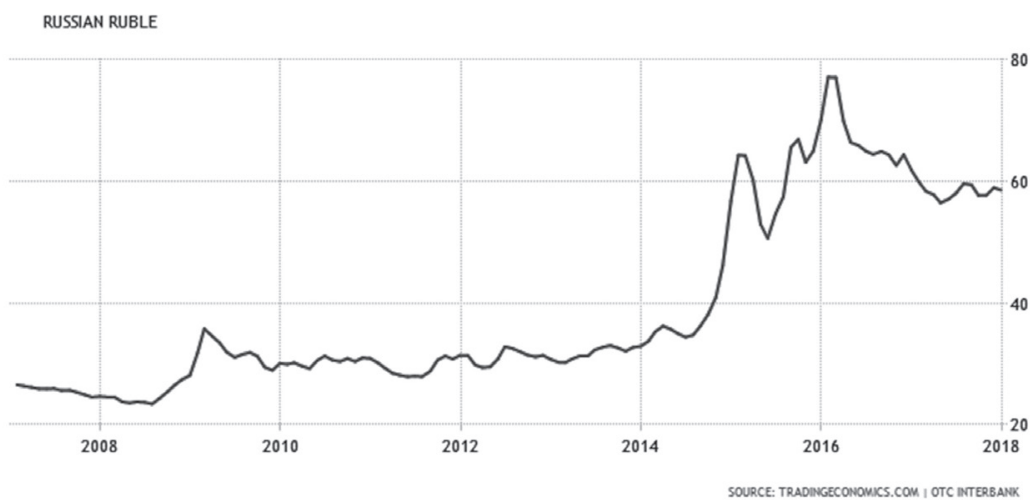

\section{Graph 2. Exchange rate of the rouble in relation to the US dollar in the period 2008-2017}

Source: Trading Economics.com, OTC Interbank. Retrieved December 4, 2017 from: https://pl.tradingeconomics. com/russia/currency, Graph: https://d3fy651gv2fhd3.cloudfront.net/charts/historical.png?s=USDRUB\&v=2017120 $5190000 \& d 1=20070101 \& d 2=20171231 \&$ type=line. 
The rouble depreciation led to many negative consequences for the economy a drop in GDP level and its growth rate, a decrease in trade with foreign states (export and import), a rise in prices of imported goods, worse conditions for the Russian export, an increase in interest rates and inflation, a drop in foreign exchange reserves etc.

It should be mentioned here that the condition of the Russian economy is strongly dependent on the levels of prices and sale of fuels, mostly crude oil, on international markets. A thesis can be put forward that in the recent years the Russian economy has exhibited strong symptoms of the "Dutch disease" - a so-called "resource curse" - that is heavy dependence on extraction and sale of natural resources. Scientific research confirms a strong adverse effect of natural resources of an economy on the rate and directions of economic growth, especially in countries with low levels of democracy and economic development (Oomes \& Kalcheva, 2007).

The fact that Russia is currently affected by the "Dutch disease" is confirmed by the latest macroeconomic data. The drop in oil price in mid-2014, lasting until today, has been reflected in a significant decrease in Russia's GDP, lower state budget revenue, a decline in foreign exchange reserves, a rise in exchange rate and many other negative effects on the economy and the society.

\section{A drop in GDP level and a slowdown in economic growth rate}

The growth rate of Russia's GDP in 2012-2017 dropped drastically - from almost $6 \%$ in 2012 to $2 \%$ in $2014,0 \%$ in 2015 , and to a decline by almost $4.5 \%$ in 2016 . Only in 2017 positive GDP growth rate was observed.

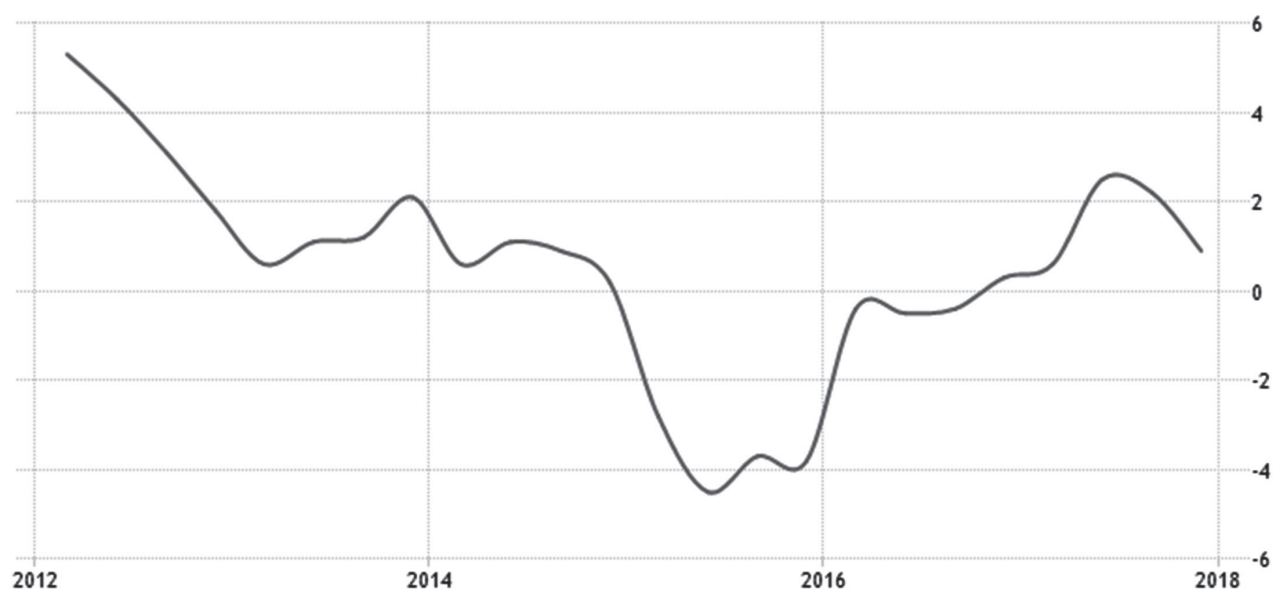

Graph 3. Rate of change in Russia's GDP in 2012-2017 (\%)

Source: Trading Economics. Retrieved December 4, 2017 from: https://pl.tradingeconomics.com/russia/gdpgrowth-annual, Graph: https://d3fy651gv2fhd3.cloudfront.net/charts/russia-gdp-growth-annual.png?s=rudpryoy\& $v=201711131314 \mathrm{v} \&$ lang=all\&d1 $=20120101 \& \mathrm{~d} 2=20171231$. 
Russia's GDP in absolute values decreased significantly after 2014 (as a result of a drop in oil prices and economic sanctions). In comparison to good 2013, Russia's GDP in 2016 decreased by almost a half.

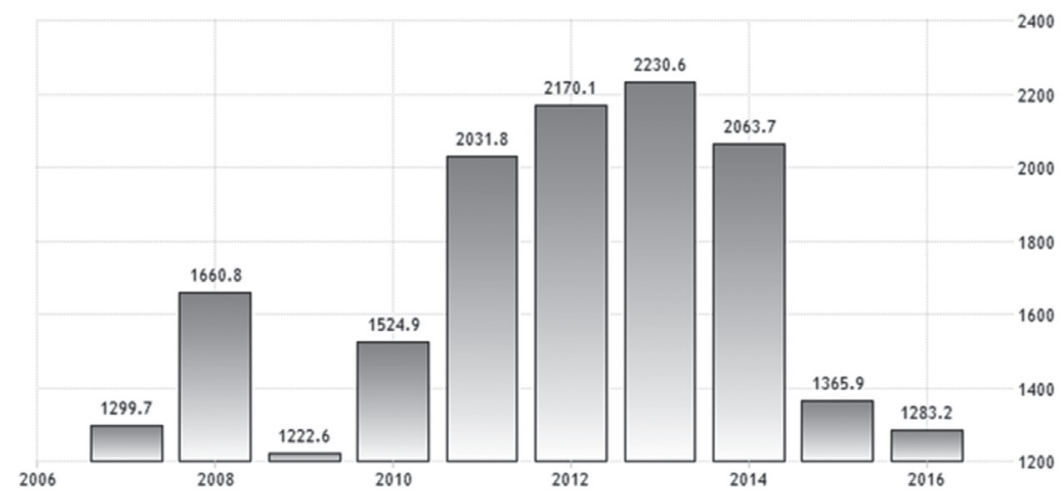

Graph 4. Russia's GDP in 2007-2016 (bn USD)

Source: Trading Economics and World Bank. Retrieved December 4, 2017 from: https://pl.tradingeconomics.com/ russia/gdp, Graph: https://d3fy651gv2fhd3.cloudfront.net/charts/russia-gdp.png?s=wgdpruss\&v=201707092232v \&lang=all.

The drop in oil price and in GDP caused a decrease in Russia's foreign exchange reserves and in the rouble exchange rate in relation to the US dollar, as it has already been mentioned.

Broadening the analysis of the impact of economic sanctions on Russia's socioeconomic development by GDP per capita confirms a deterioration of the economic situation after 2014.

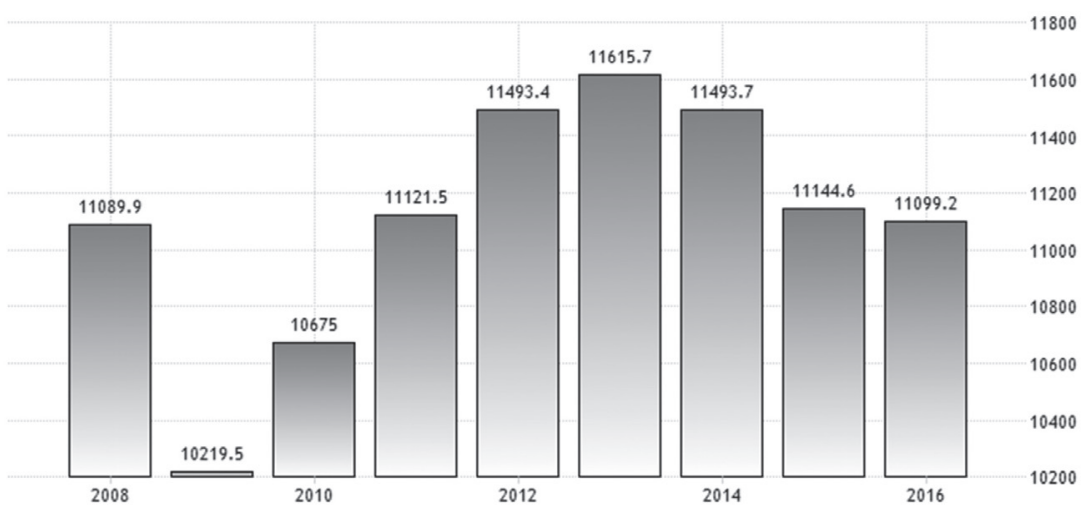

Graph 5. Russia's GDP per capita (USD)

Source: Trading Economics. Retrieved March 18, 2018 from: https://pl.tradingeconomics.com/russia/gdp-percapita, Graph: https://d3fy651gv2fhd3.cloudfront.net/charts/russia-gdp-per-capita.png?s=rusnygdppcapkd\&v=20 $1707101728 v \&$ lang=all\&d1=20080101\&d2=20181231. 
However, the subsequent data - GDP in constant prices - make it possible to say that Russia's real GDP shows only stagnation in the years 2012-2016 and not a decrease in GDP.

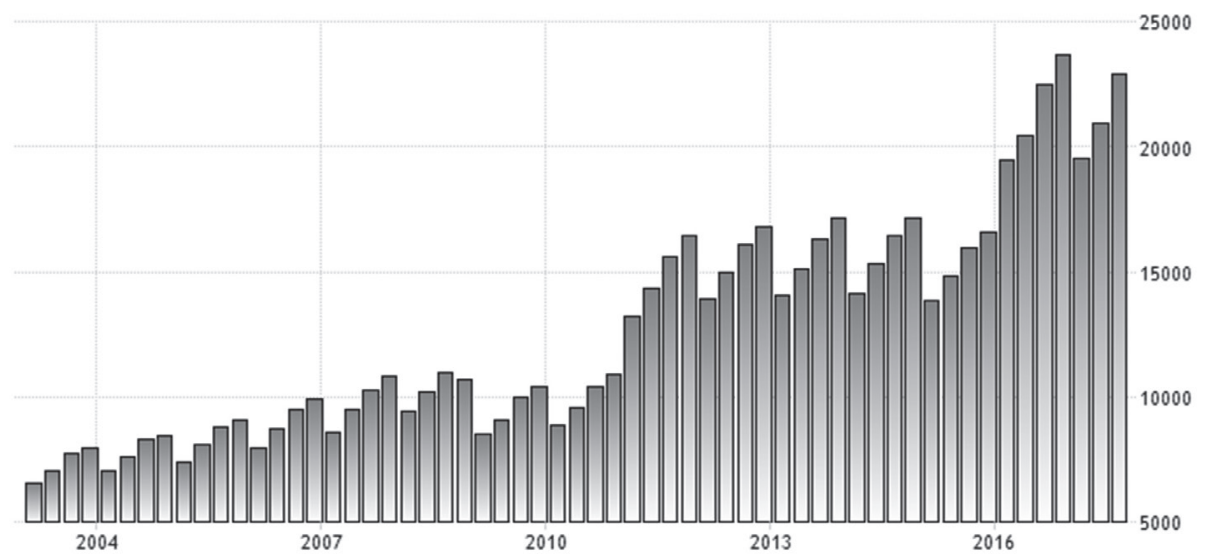

Graph 6. Russia's GDP in constant prices (bn roubles)

Source: Trading Economics. Retrieved February 22, 2018 from: https://pl.tradingeconomics.com/russia/gdp-constant-prices, Graph: https://d3fy651gv2fhd3.cloudfront.net/charts/russia-gdp-constant-prices.png?s=russiagdpco npri\&v=201712121335v\&lang=all\&d1=19180101\&d2=20181231\&type=column.

However, there is no evidence of a weakening of Russia's economic growth during the period covered by sanctions, based on the analysis of gross national product category (GNP). According to the data, Russia has systematically increased its economic growth since 1998, measured by the gross national product category.

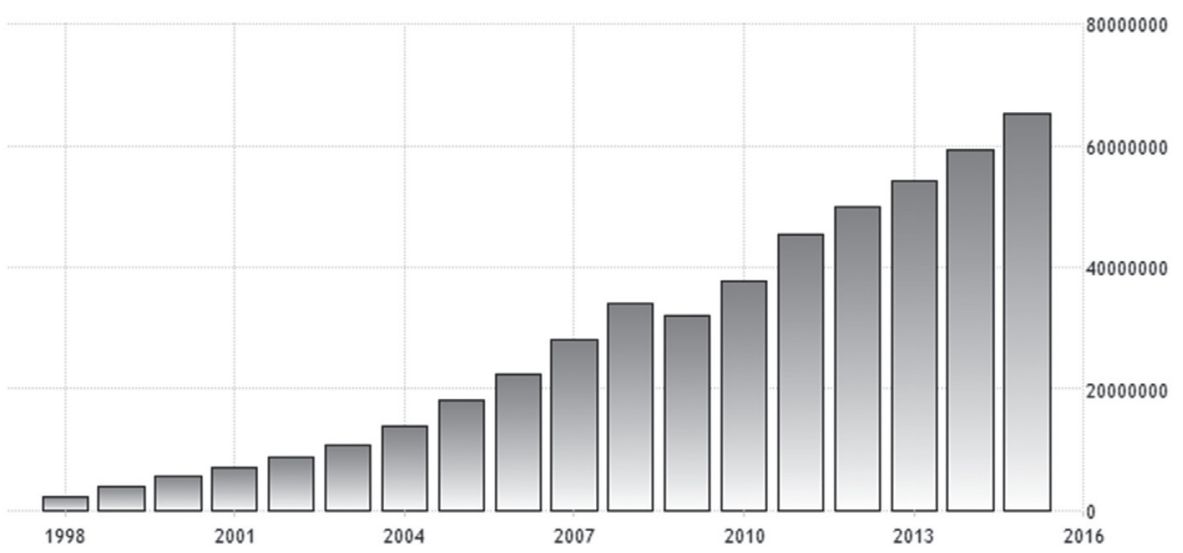

Graph 7. Gross national product of Russia (million roubles)

Source: Trading Economics. Retrieved February 22, 2018 from: https://pl.tradingeconomics.com/russia/grossnational-product, Graph: https://d3fy651gv2fhd3.cloudfront.net/charts/russia-gross-national-product.png?s=russi agronatpro\&v=201707031850v\&lang=all\&d1=19180101\&d2=20181231\&type=column . 
With high probability it can be concluded that the economic sanctions imposed against Russia have not led to a permanent weakening of the economic growth measured by GDP in constant prices and GNP. As soon as the sanctions were introduced, the growth rate declined. In the longer term, barriers to development caused by sanctions have been implanted by the economy.

\section{A drop in foreign exchange reserves}

In 2014-2017 the level of foreign exchange reserves went down considerably. While in 2014 Russia's foreign exchange reserves amounted to almost 500 bn USD (and were even higher several years before), in mid-2015 they dropped to ca. 360 bn USD, and at the beginning of 2016 they rose a little to ca. 380 bn USD. The level of Russia's foreign exchange reserves was increasing slightly to reach about 420 bn USD at the end of 2017.

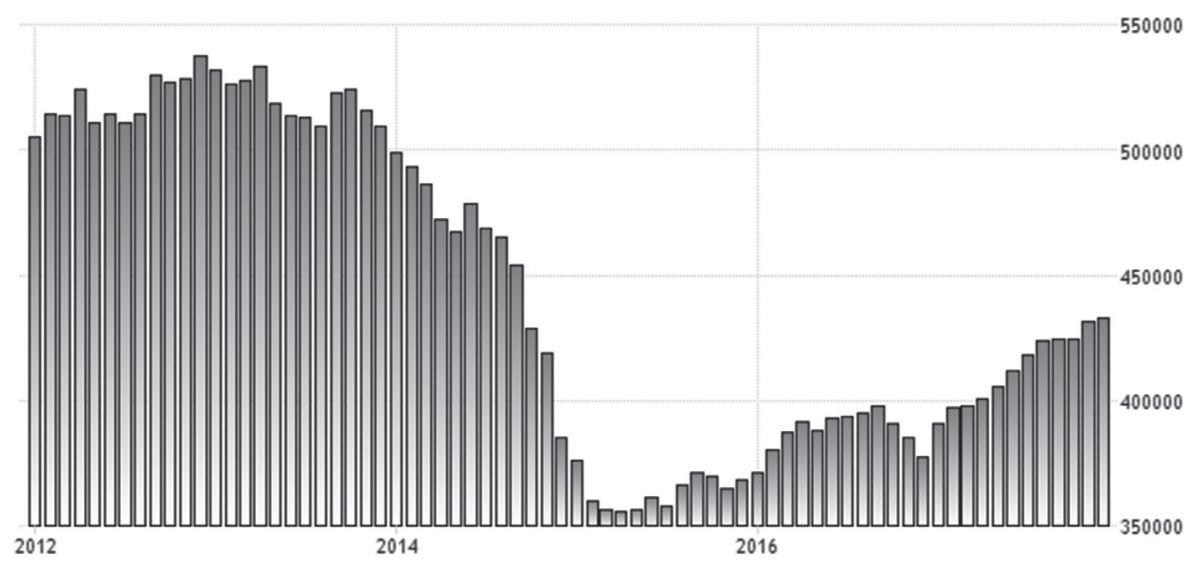

Graph 8. Russia's foreign exchange reserves in 2012-2017 (million USD)

Source: Trading Economics. Retrieved December 4, 2017 from: https://pl.tradingeconomics.com/russia/foreignexchange-reserves, Graph: https://d3fy651gv2fhd3.cloudfront.net/charts/russia-foreign-exchange-reserves.png? $\mathrm{s}=$ russiaforexcres\&v=201711091128v\&lang=all\&d1=20120101\&d2=20171231\&type=column.

\section{International trade}

The sanctions were reflected in a decline in Russia's international trade, both in export and import. In comparison to 2013, Russia's international trade decreased in total by $5.7 \%$ in 2014 and amounted to 794 bn USD. The largest drop occurred in trade with Great Britain (by 19.6\%), followed by France (16.7\%), Poland (15.8\%) and Finland (14.4\%) (Bugatova \& Abelguzin, 2015).

In the subsequent years Russia's trade with foreign states was still declining. In 2015 it amounted to 534 bn USD (of which export was 341 bn USD and import 193 bn USD). In 2016 Russia's international trade further decreased - export level was 281.8 bn USD and import 191.5 bn USD. 
Table 2. Russian export and import in 2013-2016

\begin{tabular}{|l|c|c|c|}
\hline \multicolumn{1}{|c|}{ Year } & Export & Import & Total trade \\
\hline 2013 & $523.3 \mathrm{bn}$ USD & $341.3 \mathrm{bn}$ USD & $864.6 \mathrm{bn}$ USD \\
\hline 2013 (in relation to the previous year) & $99.2 \%$ & $101.7 \%$ & $100.2 \%$ \\
\hline 2014 & $497.7 \mathrm{bn}$ USD & $308.0 \mathrm{bn}$ USD & $805.7 \mathrm{bn}$ USD \\
\hline 2014 (in relation to the previous year) & $95.1 \%$ & $90.2 \%$ & $93.2 \%$ \\
\hline 2015 & $341.4 \mathrm{bn}$ USD & $193.0 \mathrm{bn}$ USD & $534.4 \mathrm{bn}$ USD \\
\hline 2015 (in relation to the previous year) & $68.7 \%$ & $62.7 \%$ & $66.3 \%$ \\
\hline 2016 & $281.8 \mathrm{bn}$ USD & $191.5 \mathrm{bn}$ USD & $473.3 \mathrm{bn}$ USD \\
\hline 2016 (in relation to the previous year) & $82.6 \%$ & $99.3 \%$ & $88.6 \%$ \\
\hline
\end{tabular}

Source: „Biulettien Bankowskoj Statistiki”. (2014). No. 12 (271) p. 37; „Biulettien Bankowskoj Statistiki”. (2016), no. 10 (293), p. 37.

Thus, a breach in Russia's international trade is clearly visible after the introduction of sanctions in 2014. Trade turnover in 2016 fell by almost a half in relation to 2013, while a decreasing but still positive trade balance was maintained.

As a result of the rouble depreciation, prices of imported goods rose and, in consequence, import to Russia was reduced. In the first half of 2015 import of furniture, cotton, medicines, shoes and passenger cars went down by almost a half in comparison to the analogous period of 2014. Import of trucks in the same period reached only $20 \%$ of the import level from the first half of 2014 (Nuriejev, \& Pietrakov, 2016).

\section{An increase in interest rates}

One of the consequences of the sanctions introduced against Russia was an increase in interest rates of the central bank. At the turn of 2014/2015 interest rate was raised from $5.5 \%$ to $17 \%$. In the first half of 2015 interest rate was reduced to $11 \%$ and then became stabilized at the same level until mid-2016. After that time it started to go down and reached a level of ca. $8.5 \%$ at the end of 2017.

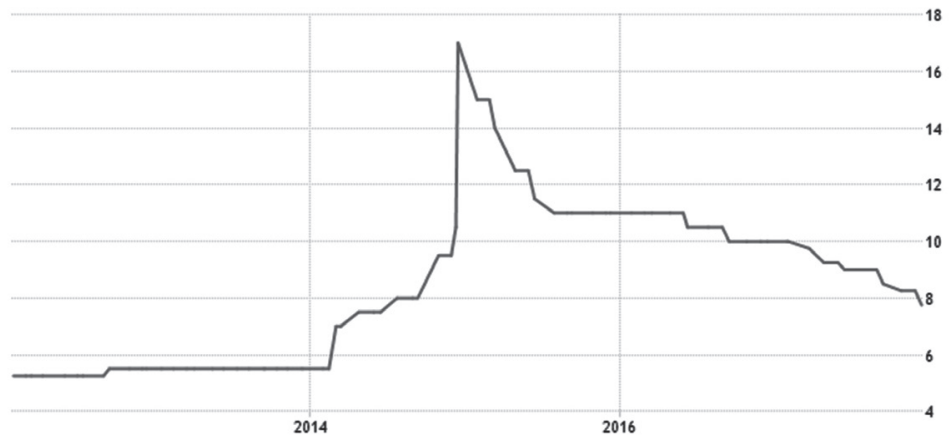

Graph 9. Interest rate of the central bank in Russia in 2012-2017 (\%)

Source: Trading Economics. Retrieved December 4, 2017 from: https://pl.tradingeconomics.com/russia/interestrate. Graph: https://d3fy651gv2fhd3.cloudfront.net/charts/russia-interest-rate.png?s=rrefrate\&v=201710271043v \&lang=all\&d1 $=20120101 \& d 2=20171231$. 
One of the reasons for the increase in interest rate was the introduction of sanctions consisting in limited financing of the leading Russian enterprises and banks on the international financial market. Access to sources of financing on the international markets was also limited for Russian exporters and importers. This resulted in a lower supply of money in the Russian economy and enforced a rise in interest rates of the central bank. The increase in interest rates and the decrease in money supply in the Russian economy resulted in a slowdown in the economic growth rate of Russia with its numerous consequences.

\section{Change in inflation level}

As a result of the economic sanctions, a rise in inflation level was observed, measured by the core inflation indicator, prices of consumer goods and administered prices. In 2014 - the year when the sanctions were introduced - the inflation rate rose from $5-6 \%$ to $12 \%$, in 2015 from $12 \%$ to over $17 \%$ in the first half of the year, but in the second half of the year the rate of inflation growth became slower and finally the core inflation reached $12 \%$ at the end of 2015. In 2016 the inflation rate decreased to ca. 5\% at the end of the year. In 2017 the inflation rate was still going down and at the end of the year it reached negative values (disinflation) (Godovoj Otcziot Banka Rossii, 2017).

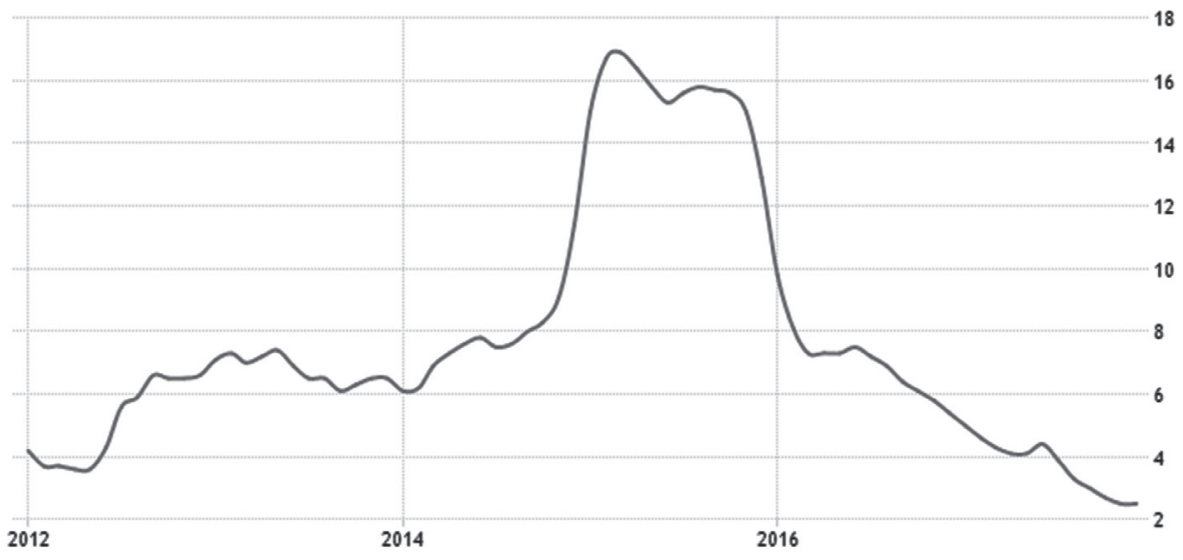

Graph 10. Inflation rate (yearly) in Russia in 2012-2017 (\%)

Source: Trading Economics. Retrieved December 12, 2017 from: https://pl.tradingeconomics.com/russia/inflationrate-mom. Graph: https://d3fy651gv2fhd3.cloudfront.net/charts/russia-inflation-cpi.png?s=rucpiyoy\&v=201712051 518v\&lang=all\&d1=20120101\&d2=20171231\&type=spline.

The highest increase in prices in 2014-2016 was observed in the group of consumer goods - some prices went up even by $25 \%$. 


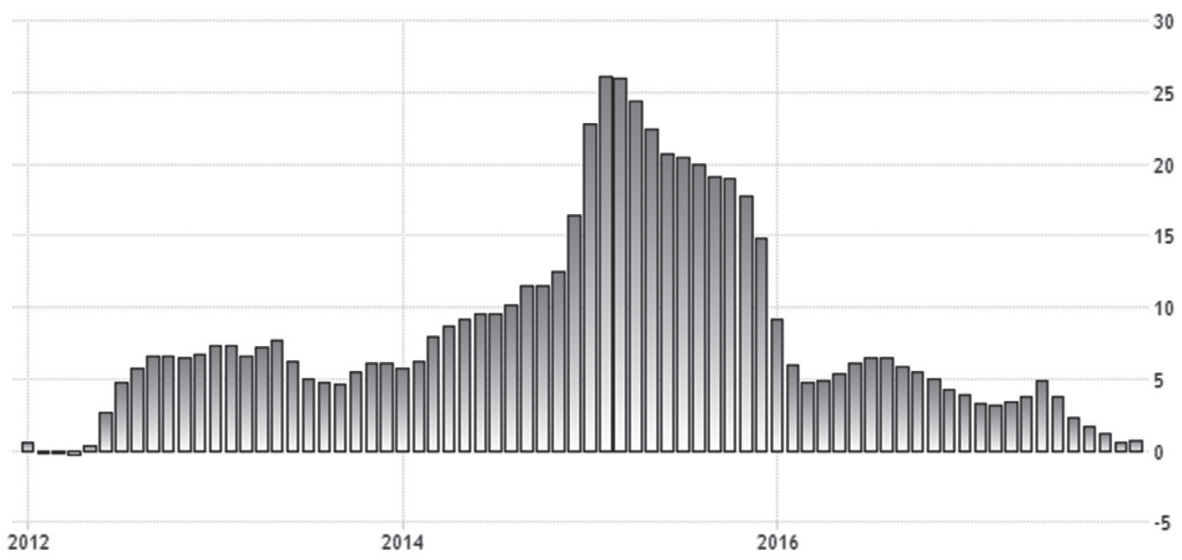

Graph 11. Increase in food prices in Russia (month to month) in 2012-2017 (\%)

Source: Trading Economics. Retrieved January 4, 2017 from: https://pl.tradingeconomics.com/russia/food-inflation. Graph: https://d3fy651gv2fhd3.cloudfront.net/charts/russia-food-inflation.png?s=russiafooinf\&v=2017110713 18v\&lang=all\&d1=20120101\&d2=20171231\&type=column.

Since the beginning of 2017 a decrease in inflation could be observed, from the level of ca. $5 \%$. Thus, it can be claimed that, as a result of the introduction of sanctions, the Russian economy experienced a kind of a price shock and inflation growth but it soon absorbed this shock and in 2017 inflation became stabilized at the level of 2-3\% yearly. This is beneficial for the Russian economy.

\section{An increase in interest rates on bank loans}

Another consequence of the economic sanctions against Russia is a decline in granting credit to the economy and population and an increase in interest rate on loans. Restrictions on granting credit to Russian enterprises and banks on the international market (the EU, USA, Canada and Switzerland) caused a drop in money supply on the Russian money market and forced the Russian central bank (Bank of Russia) to raise interest rates. Bank of Russia raised the basic interest rate from $5.5 \%$ to $17 \%$ already in 2014. This intensified tensions on the Russian money market and led to a decline in credit granting and to a slowdown in GDP growth rate.

The increase in interest rates on bank loans has adversely affected the consumers in three ways (Nuriejev \& Pietrakov, 2015):

a) many enterprises became insolvent due to higher costs of credit, which resulted in unemployment growth,

b) consumer loans and mortgage loans became more expensive,

c) weakening of the rouble led to a rise in prices of imported goods and reduction in their consumption, also due to lower import of many foreign goods. 
The increase in interest rates caused insolvency of many borrowers and delays in repayment of loans. Overdue loans in banks rose almost twofold in 2014-2015 (from 861.3 bn roubles at the beginning of 2014 to $1,634.2$ bn roubles in December 2015). This has a negative impact on stabilization of the Russian banking system (Nuriejev \& Pietrakov, 2016).

\section{Changes in level and quality of consumption}

The introduction of economic sanctions and the increase in exchange rate caused in 2014 a significant decline in import of meat and fish (by $30 \%$ on average), pork only by as much as $50 \%$, cheese by $20 \%$, flour, cereals and cereal products by as much as 40\%. This downward trend in import became even stronger in 2015 (in comparison to 2014). Import of dairy products, poultry and meat dropped the most significantly. As a result, consumption of highly processed food from abroad has decreased, whereas demand and consumption of food produced in Russia have risen (Temrokova, 2017). According to Russian experts, consumption of more ecological products has grown (Nuriejev \& Pietrakov, 2016).

\section{Conclusions}

To sum up, the Russian economy after 2014 experienced a major shock which adversely affected its development. This shock was caused by three factors:

a) economic sanctions imposed on Russia,

b) a drop in oil price,

c) inefficient economic policy of the Russian government during that period.

In summary, as a result of the economic sanctions applied by the Western states against Russia and the cumulated influence of adverse external and internal conditions of economic growth in 2014-2016, the Russian economy experienced many losses (Bugatova \& Abelguzin, 2015).

In economy, a slowdown of economic growth rate and GDP decrease in absolute values were observed. Reduced income from oil and gas sale complicated the situation of the state budget. Inflation and prices (especially of food) rose. As a consequence of price increase, global demand fell which led to formation of market balance on a new level, with lower GDP and higher prices. Moreover, interest rates and interest on loans went up, and the amount of overdue loans and insolvency of many borrowers increased. Russian entities experienced difficulties or lack of access to foreign credit. Furthermore, trade with foreign countries decreased considerably, the level of foreign exchange reserves went down, and the national currency became strongly depreciated. The decrease in national currency value and uncertainty in economy led to increased withdrawals of bank deposits and problems of banks with liquidity. Financial stability deteriorated 
seriously, we can even talk about a banking crisis caused by withdrawals of deposits by people as a result of the rouble devaluation. Foreign entities began to withdraw from the Russian economy and foreign assets were taken away: it is estimated that foreign capital outflow amounted to ca. 130 bn USD during that period. Other consequences of the economic sanctions are: a drop in prices on the real estate market, a decline in foreign tourism and a decrease in spending of Russian citizens in such countries as: USA, Great Britain, Italy, Finland and France, but on the other hand a growth in tourist trips to former CIS states and development of domestic tourism. As a result of lower optimism among investors, a crisis in small business has been observed, a lower number of newly opened companies and a higher number of closed businesses.

It should also be noted that in response to the sanctions imposed, Russia introduced administrative restrictions on export and import, and free movement of goods, capital and people was limited. The sanctions imposed by Russia have influenced the economies of the Western states which have also experienced worse conditions of economic growth after 2014.

\section{References}

„Biulettien Bankowskoj Statistiki” (2014). №. 12 (271).

"Biulettien Bankowskoj Statistik" (2016). №. 10 (293).

Barkowskij A.N., Ałabjan S.S. (2015). Posledstvija zapadnych sankcji i otvietnych sankcji RF, „Rossijskij Wniesznieekonomiczeskij Wiestnik”. No. 9, pp. 3-7.

Bugatova A.I., \& Abelguzin N. R. (2015). Vlijanije sankcji na ekonomiku Rossii, „Aktualnyje Problemy Ekonomiki i Prawa", 3, 26-37.

Chronologia unijnych sankcji stosowanych w odpowiedzi na kryzys na Ukrainie. (2017). Retrieved July 8, 2017 from: http://www.consilium.europa.eu/pl/policies/sanctions/ukraine-crisis/.

Dobre praktyki w zakresie skutecznego wprowadzania w życie środków ograniczających. (2016). Godovoj Otcziot Banka Rossii za god 2016. (2017). Moskwa.

Kiedy i jak UE przyjmuje sankcje. (2017). Retrieved July 8, 2017 from: http://www.consilium. europa.eu/pl/policies/sanctions/ukraine-crisis/.

KublikA. (2016, September 1). USA rozszerzają sankcje na Rosję. Na czarnej liście spółki Gazpromu. RetrievedFebruary18,2018from: http://wyborcza.biz/biznes/1,100896,20632865, usarozszerzaja-sankcje-na-rosje-na-czarnej-liscie-spolki-gazpromu.html?disableRedirects=true.

List of persons and entities under $E U$ restrictive measures over the territorial integrity of Ukraine. (2017). Retrieved December 13, 2017 from: http://www.consilium.europa.eu/media/21891/ 20170914-list-of-designated-persons-and-entities.pdf.

Łoginova I.V., \& Titarienko B. A. (2015). Ekonomiczeskije sankcji protiv Rossii. „Aktualnyje Voprosy Ekonomiczeskich Nauk". No. 47, 41-42.

Nowicki M. (2017). Sankcje niszczą Rosję. UE traci 17,6 mld euro. Retrieved January 5, 2017 from: http://niezalezna.pl/91764-sankcje-niszcza-rosje-ue-traci-176-mld-euro. 
Nuriejev R. M., \& Pietrakov P.K. (2015). Riadovoj potriebitiel: vriemija ekonomiczeskich sankcji protiv Rossii. „Journal of Economic Regulation, Voprosy regulirovanija ekonomiki”, volume 6 , 3, 39-60.

Nuriejev R. M., \& Pietrakov P.K. (2016). Ekonomiczeskije sankcji protiv Rossii: ożidanija i realnost. „Mir Novoj Ekonomiki”. No. 3, 14-31.

Oomes N., \& Kalcheva K. (2007, April). Diagnosing Dutch Disease: Does Russia Have The Symptoms. „IMF Working Paper” WP 07/102, 1-34.

Portal Trading Economics (2017). Retrieved December 4-15, 2017 from: https://pl.tradinge conomics.com/.

Rodzaje sankcji. (2017). Retrieved December 4, 2017 from: http://www.consilium.europa.eu/pl/ policies/sanctions/different-types/.

Rosja potępiła sankcje Kanady na 30 jej obywateli. (2017). Retrieved November 5, 2017 from: http://wiadomosci.onet.pl/swiat/rosja-potepila-sankcje-kanady-na-30-jej-obywateli/fvkp03b.

Sankcii Kanady w otnoszenii k Rossii, Informacionnoje Agientsvo TASS. (2017). Retrieved November 5, 2017 from: http://tass.ru/info/4702366.

Temrokova A. H., (2017). Importozamieszczenije v sovriemiennych usłovijach prieodolenija ekonomiczeskich sankcji, Naucznyje Izwestia, no. 7, 42-46.

Unijne sankcje w odpowiedzi na kryzys na Ukrainie. (2017). Retrieved December 4, 2017 from: http://www.consilium.europa.eu/pl/policies/sanctions/ukraine-crisis/.

Wsie sankcji zapada protiw Rosii. (2017). Retrieved October 8, 2017 from: http://tass.ru/ mezdunarodnaja-panorama/1055587/2.

Wsie sankcii zapada protiw Rosii. (2017). Retrieved October 8, 2017 from: http:/tass.rul mezdunarodnaja-panorama/1055587/4.

Wsie sankcii zapada protiw Rosii. (2017). Retrieved October 8, 2017 from: http:/tass.rul mezdunarodnaja-panorama/1055587/5.

Wsie sankcii zapada protiw Rosii. (2017). Retrieved October 8, 2017 from: http:/tass.rul mezdunarodnaja-panorama/1055587/7.

Wsie sankcii zapada protiw Rosii. (2017). Retrieved October 8, 2017 from: http:/tass.rul mezdunarodnaja-panorama/1055587/8.

Wytyczne UE w sprawie stosowania i oceniania środków ograniczających. (2012). 